\title{
Haemodynamic adaptation at rest and during exercise to long-term antihypertensive treatment with combined alpha- and beta-adrenoreceptor blockade by labetalol
}

Animal and human studies have shown that hypertension rapidly induces structural changes in the precapillary resistance vessels, including reduced internal vessel radius, increased wall to lumen ratio, and a consequent hyperactivity of these vessels with exaggerated luminal reductions for a given smooth muscle activation (Folkow, 1975). Recent studies also suggest that these structural changes may be reversible under certain conditions, both in the experimental animal (Weiss et al., 1974) and in man (Sivertsson, 1977). Constriction of the peripheral resistance vessels is mediated through $\alpha$-adrenoreceptors. Thus blockade of these receptors appears on theoretical grounds to be the most

Received for publication 27 January 1978 logical and efficient way to lower precapillary resistance and to damp the functional excitatory influences which, once the structural changes are established, enhance increases in the vascular pressure load and in turn serve to intensify the structural adaptation.

Agents with $\alpha$-adrenoreceptor blocking properties such as phentolamine (Majid et al., 1974) and labetalol (Koch, 1976b) have consistently been shown to reduce systemic vascular resistance and thereby blood pressure in man, at least in the acute experiment. As labetalol combines alpha-receptor with beta-receptor blocking properties it has an essential advantage over phentolamine and other peripheral vasodilators such as hydralazine and prazosin (Zacest, 1975), in that it counteracts the 192 
baroreceptor reflex increase of heart rate and cardiac output elicited by the pressure decrease.

Labetalol has been shown to have a considerable antihypertensive action (Richard and Turner, 1976; Brogden et al., 1978). In the acute experiment it reduces blood pressure, at rest and during exercise, by lowering both the systemic vascular resistance and cardiac output but not stroke volume (Koch, 1976b, 1977). This pattern of haemodynamic effect distinguishes labetalol from most if not all other single antihypertensive drugs and offers a particularly attractive basis for treating hypertension from the physiological point of view.

Our knowledge of the haemodynamic effects of labetalol relates at present mainly to the acute intravenous administration of the drug. However it is well established that with many agents interfering with cardiovascular regulation, including antihypertensive drugs, the acute haemodynamic effects are attenuated or modified after prolonged treatment (Koch, 1976a). The purpose of the present study was, therefore, to define the long-term effects of oral labetalol with respect to circulatory dynamics. The haemodynamic effects on the systemic and pulmonary circulations in patients with essential hypertension have been investigated during rest in both supine and upright positions and during exercise.

\section{Patients}

Of the 13 patients who had participated in the initial investigation (Koch, 1977a), 9 men aged 49 to 57 years were restudied after an average of 20 months (range 16 to 24 months) treatment with oral labetalol as the sole antihypertensive agent in doses ranging from 600 to $2400 \mathrm{mg}$ daily. Doses had to be repeatedly increased during the initial 6 months of oral treatment in order to maintain a similar blood pressure reduction as that obtained after the intravenous administration of labetalol; subsequently the dosage could be kept unchanged or slightly reduced.

The clinical evaluation indicated that all patients had essential hypertension; plasma volume, blood counts, serum electrolytes, serum creatinine, liver and renal function tests were normal and virtually unchanged during the entire period of observation. In particular, there was no case of positive antinuclear factor during a total observation time exceeding 3 years. Fundoscopic examination before and after the 20-month period did not reveal any significant alteration: one patient had no abnormalities at all, the remainder had non-exudative grade 1 to 2 hypertensive changes. None had . evidence of ischaemic heart disease as evaluated by repeated exercise electrocardiograms (maximal work load ranging between 150 and 200 Watts) or of significant cardiac enlargement. Some relevant patient data including blood volume, heart volume, total amount of haemoglobin, and plasma renin activity before, and their changes after, the 20month period, are given in Table 1.

Table 1 Means and standard deviations (SD) of some anthropometric data and of plasma renin activity $(P R A)$ before and mean $(\bar{D})$ and percentage $(\bar{D} \%)$ changes after 20 months of antihypertensive treatment

\begin{tabular}{lcccc}
\hline & Mean & $S D$ & $\bar{D}$ & $\bar{D} \%$ \\
\hline Age (y) & 53.8 & 2.6 & 1.8 & 3.2 \\
Weight (kg) & 83.4 & 8.1 & -1.5 & -1.8 \\
Height (cm) & 176.3 & 6.0 & 0 & 0 \\
Blood volume (1) & 6.49 & 1.24 & -0.45 & -6.9 \\
Total Hb (g) & 859 & 202 & -92 & -10.7 \\
PRA (ng/ml per h) & 2.10 & 1.96 & $-1.3 \star \star$ & $-63.0 \star \star$ \\
\hline
\end{tabular}

$\star \star P<0.01$.

\section{Methods}

Haemodynamics were restudied after the 20month period of oral treatment in precisely the same way and under conditions identical to the initial haemodynamic investigation. The haemodynamic measurements were made both in the supine and the upright positions and during steady state exercise at two different work loads $\left(W_{1}\right.$ : $62 \pm 8$, mean \pm standard deviation, range 50 to $75 \mathrm{~W} ; \mathrm{W}_{2}: 124 \pm 16$, range 100 to $150 \mathrm{~W}$ ) in the sitting position on a bicycle ergometer.

Both the orthostatic test and exercise at each work load lasted for 6 minutes. Systemic and pulmonary arterial pressures were directly recorded through polyvinyl catheters percutaneously introduced into the left brachial artery and the main pulmonary artery. Cardiac output was determined according to the Fick principle. Details concerning the general investigation procedure, analyses, calculations, including the reproducibility of the methods used and the statistical evaluation, are given elsewhere (Koch, 1976a, 1977).

\section{Results}

HAEMODYNAMICS AFTER LONG-TERM ORAL TREATMENT

Mean values and standard deviations of some relevant haemodynamic indices as measured before, as well as the changes observed after treatment, are given in Tables 2 and 3 and in Fig. 1. 
Table 2 Means and standard deviations (SD) of blood pressures and vascular resistances before and their mean changes $(\bar{D})$ after 20 months of antihypertensive treatment at rest in supine $(R)$ and upright $(O)$ position and during exercise at two different work loads

\begin{tabular}{|c|c|c|c|c|}
\hline & & Mean & $S D$ & $\bar{D}$ \\
\hline $\begin{array}{l}\text { Brachial artery } \\
\text { Systolic pressure (mmHg) }\end{array}$ & $\begin{array}{l}\mathrm{R} \\
\mathrm{O} \\
\mathrm{W}_{1} \\
\mathrm{~W}_{2}\end{array}$ & $\begin{array}{l}167 \\
174 \\
198 \\
235\end{array}$ & $\begin{array}{l}24 \\
31 \\
31 \\
23\end{array}$ & $\begin{array}{l}-18^{\star} \\
-27^{\star \star} \\
-42^{\star \star} \\
-57^{\star \star}\end{array}$ \\
\hline Diastolic pressure (mmHg) & $\begin{array}{l}\mathrm{R} \\
\mathrm{O} \\
\mathrm{W}_{1} \\
\mathrm{~W}_{\mathrm{y}}\end{array}$ & $\begin{array}{r}98 \\
104 \\
100 \\
111\end{array}$ & $\begin{array}{l}13 \\
17 \\
16 \\
17\end{array}$ & $\begin{array}{l}-17^{\star \star} \\
-19^{\star \star} \\
-20^{\star} \\
-26^{\star \star}\end{array}$ \\
\hline Mean pressure $(\mathrm{mmHg})$ & $\begin{array}{l}\mathrm{R} \\
\mathrm{O} \\
\mathrm{W}_{1} \\
\mathrm{~W}_{2}\end{array}$ & $\begin{array}{l}124 \\
133 \\
143 \\
162\end{array}$ & $\begin{array}{l}15 \\
22 \\
18 \\
20\end{array}$ & $\begin{array}{l}-18^{\star \star} \\
-23^{\star \star} \\
-32^{\star \star} \\
-37^{\star \star}\end{array}$ \\
\hline $\begin{array}{l}\text { Pulmonary artery } \\
\text { Systolic pressure (mmHg) }\end{array}$ & $\begin{array}{l}\mathrm{R} \\
\mathrm{O} \\
\mathbf{W}_{1} \\
\mathbb{W}_{2}\end{array}$ & $\begin{array}{l}22 \\
19 \\
30 \\
36\end{array}$ & $\begin{array}{l}6 \\
6 \\
6 \\
9\end{array}$ & $\begin{aligned} & 3 \\
- & 2 \\
5^{\star} & 5\end{aligned}$ \\
\hline Diastolic pressure $(\mathrm{mmHg})$ & $\begin{array}{l}\mathrm{R} \\
\mathrm{O} \\
\mathrm{W}_{1} \\
\mathrm{~W}_{2}\end{array}$ & $\begin{array}{r}4 \\
3 \\
7 \\
11\end{array}$ & $\begin{array}{l}3 \\
3 \\
2 \\
4\end{array}$ & $\begin{array}{l}4 \\
1 \\
5 \\
4\end{array}$ \\
\hline Mean pressure (mmHg) & $\begin{array}{l}\mathrm{R} \\
\mathrm{O} \\
\mathbb{W}_{1} \\
\mathbb{W}_{2}\end{array}$ & $\begin{array}{r}11 \\
8 \\
16 \\
21\end{array}$ & $\begin{array}{l}4 \\
4 \\
5 \\
7\end{array}$ & $\begin{array}{l}3 \\
1 \\
6^{\star} \\
8^{\star}\end{array}$ \\
\hline $\begin{array}{l}\text { Systemic vascular resistance } \\
\text { index } \\
\text { Pulmonary vascular resistance } \\
\text { index }\end{array}$ & $\begin{array}{l}\mathrm{R}^{2} \\
\mathrm{O} \\
\mathrm{W}_{2} \\
\mathrm{R} \\
\mathrm{O} \\
\mathrm{W}_{2}\end{array}$ & $\begin{array}{r}48 \cdot 8 \\
57 \cdot 4 \\
25 \cdot 7 \\
3 \cdot 0 \\
2 \cdot 4 \\
1 \cdot 6\end{array}$ & $\begin{array}{r}12.1 \\
14.7 \\
5.8 \\
1.3 \\
1.2 \\
0.6\end{array}$ & $\begin{array}{c}9 \cdot 3^{\star} \\
-13 \cdot 6^{\star} \\
-4^{\star} \cdot 4^{\star} \\
-0 \cdot 7^{\star} \\
0 \\
0 \cdot 8^{\star}\end{array}$ \\
\hline
\end{tabular}

$\star \mathbf{P}<0.05$

$\star \star \mathbf{P}<0.01$.

$W_{1}=62$ Watts;

$W_{2}=124 W_{\text {atts. }}$

The pretreatment average systemic blood pressure was $167 / 98$ (mean 124) $\mathrm{mmHg}$ at rest in the supine and 174/104 (mean 133) $\mathrm{mmHg}$ in the upright position. It rose to $235 / 111$ (mean 162) $\mathrm{mmHg}$ during exercise $\left(\mathrm{W}_{2}\right)$. Treatment with oral labetalol resulted in a significant reduction (by 11 to $25 \%$ ) under all conditions, the effect being most pronounced during exercise. At rest, both in the supine and upright posture, mean and diastolic pressures were affected more than systolic pressures.

Blood pressures in the pulmonary circulation were within normal limits both before and after treatment. Except for upright conditions there was a general tendency towards slightly higher values after treatment, in particular as regards systolic $\left(P<0.05, W_{1}\right)$ and mean pressures $\left(P<0.05, W_{1}\right.$ and $W_{2}$ ) during exercise. However, the absolute changes in pressure were minimal.

Heart rates were significantly reduced during all conditions (by 13 beats in the supine position and 28 beats during $\left.\mathrm{W}_{2}\right)$; oxygen uptake $\left(\mathrm{V}_{2}\right)$ and ventilation $(\dot{V} E)$ were unaffected.

Because of a significant increase in stroke volumewhich fully counterbalanced the reduction in heart rate, cardiac output was virtually unchanged. The arteriovenous oxygen difference was slightly reduced in the supine position only.

Pretreatment systemic vascular resistances weregreatly increased at rest, both in the supine and especially in the upright positions. They were considerably reduced during all conditions after treatment (by 19 to $27 \%$ ). Pulmonary vascular resistances were low before and after treament, and did not show any consistent change during the 20month period.

Plasma renin activity (Table 1) and arterial blood lactate levels were significantly reduced. (by 35 to $65 \%$ ) under all conditions. 
Table 3 Means and standard deviations $(S D)$ of some circulatory and respiratory variables before and their mean changes $(\bar{D})$ after 20 months of antihypertensive treatment at rest in supine $(R)$ and upright $(O)$ position, and during exercise at two different work loads

\begin{tabular}{|c|c|c|c|c|}
\hline & & Mean & $S D$ & $\bar{D}$ \\
\hline \multirow[t]{3}{*}{ Heart rate } & $\mathbf{R}$ & 72 & 8 & 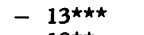 \\
\hline & O & 81 & 14 & $-18^{\star \star}$ \\
\hline & $W_{3}$ & 139 & 20 & $-28^{\star \star}$ \\
\hline \multirow[t]{3}{*}{ Ventilation $\dot{V}_{E}(1 / \min$ BTPS $)$} & $\mathbf{R}$ & $11 \cdot 6$ & $4 \cdot 6$ & -1.4 \\
\hline & 0 & $15 \cdot 5$ & $5 \cdot 0$ & $-2 \cdot 6$ \\
\hline & $\mathrm{W}_{\mathbf{2}}$ & $56 \cdot 6$ & $10 \cdot 5$ & $2 \cdot 3$ \\
\hline \multirow{3}{*}{$\begin{array}{l}\text { Oxygen uptake, } \dot{\mathrm{V}}_{2}(1 / \mathrm{min} \\
\text { STPD) }\end{array}$} & $\mathbf{R}$ & 262 & 42 & -3 \\
\hline & O & 351 & 66 & -43 \\
\hline & $\mathrm{W}_{2}$ & 1805 & 184 & -115 \\
\hline \multirow[t]{3}{*}{$\mathrm{AVO}_{2}$ difference $(\mathrm{ml} / \mathrm{l})$} & $\mathbf{R}$ & $51 \cdot 0$ & 11 & -3 \\
\hline & $\mathbf{0}$ & 76.0 & 12 & $-13^{\star \star}$ \\
\hline & $\mathrm{W}_{2}$ & $139 \cdot 6$ & 12 & -2 \\
\hline \multirow[t]{3}{*}{ Cardiac output ( $1 / \mathrm{min})$} & $\mathbf{R}$ & $5 \cdot 42$ & $1 \cdot 57$ & $0 \cdot 13$ \\
\hline & $\mathbf{0}$ & 4.81 & 1.21 & $0 \cdot 21$ \\
\hline & $\mathbb{W}_{2}$ & 13.06 & $1 \cdot 87$ & -0.71 \\
\hline \multirow[t]{3}{*}{ Stroke volume $(\mathrm{ml})$} & $\mathbf{R}$ & 75 & 20 & $22^{\star}$ \\
\hline & $\mathbf{O}$ & 65 & 21 & 16 \\
\hline & $W_{2}$ & 94 & 11 & 17 \\
\hline \multirow[t]{4}{*}{ Lactate $(\mathrm{mmol} / \mathrm{l})$} & $\mathbf{R}$ & 0.97 & 0.39 & $-0.57^{\star \star}$ \\
\hline & o & 1.01 & 0.47 & $-0.66^{\star \star}$ \\
\hline & $\mathbb{W}_{2}$ & 3.93 & 0.71 & 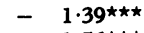 \\
\hline & $4^{\prime}$ after work & $4 \cdot 39$ & 1.05 & $1 \cdot 56^{\star \star \star}$ \\
\hline
\end{tabular}

$\mathrm{W}_{1}=62 \mathrm{~W} ; \mathrm{W}_{2}=124 \mathrm{~W}$.

$\star P<0.05$

$\star \star \mathbf{P}<0.01$

$\star \star \star P<0.001$.

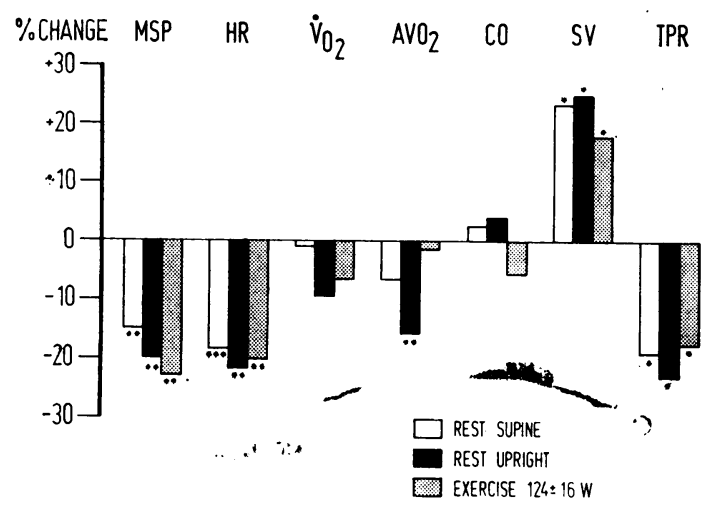

Fig. 1 Percentage changes from pretreatment values of some haemodynamic variables after 20 months of antihypertensive treatment. MSP, mean systemic blood pressure; $H R$, heart rate; $V \mathrm{O}_{2}$, oxygen uptake; $A V \mathrm{O}_{2}$, arterio-mixed venous oxygen difference; $C O$, cardiac output; $S V$, stroke volume; $T P R$, total peripheral resistance. Asterisks denote level of statistical significance: ${ }^{*} P<0.05$, $* * P<0.01, * * * P<0.001$.

HAEMODYNAMICS AFTER LONG-TERM ORAL TREATMENT COMPARED WITH ACUTE INTRAVENOUS TREATMENT

Fig. 2 denotes the changes in the main haemodynamic indices that were observed after oral treatment compared with the haemodynamics as induced by 
upright position, $\mathrm{P}<0.05$ ) resulting in slightly increased cardiac output. In accordance with the increased cardiac output the arteriovenous oxygen difference was significantly lower, particularly in the upright position. The systemic vascular resistance showed a further tendency towards lower values at rest.

\section{Discussion}

Treatment with oral labetalol for an average duration of 20 months resulted in considerably lower blood pressures under all conditions. Systemic mean pressures were reduced by 18 and 23 $\mathrm{mmHg}$ at rest in the supine and erect posture, and by 32 and $37 \mathrm{mmHg}$ during exercise at loads $W_{1}$ $(62 \pm 8 \mathrm{~W})$ and $\mathrm{W}_{2}(124 \pm 16 \mathrm{~W}$ corresponding to an oxygen uptake of approximately 1.81 ), respectively.

The mode of antihypertensive action was practically identical at rest, both in the supine and erect posture, and during exercise. Blood pressure was lowered by a reduction of peripheral vascular resistance alone; though heart rate was significantly lower under all conditions, cardiac output was virtually unchanged because of a considerable increase in stroke volume which entirely counterbalanced the reduction in pulse rate. It is particularly noteworthy that the increase in stroke volume which was consistently observed under all conditions was achieved without any significant rise in pulmonary artery diastolic pressure, that is in left ventricular filling pressure. Though the use of left ventricular filling pressure as a method of evaluating myocardial contractility is crude and insensitive, the absence of any significant pressure rise both at rest and particularly during exercise, in association with considerably increased stroke volumes, suggests that labetalol lacks significant negative inotropic effects.

A completely different pattern of haemodynamic adaptation is regularly seen with agents that exclusively block adrenergic beta-receptors. In the rare instances when left ventricular filling pressures were measured during long-term oral treatment with beta-blockers, left ventricular filling pressures were regularly found to be higher at corresponding exercise levels. This applies for oxprenolol and propranolol (Taylor et al., 1970) as well as for the combination of oxprenolol and hydralazine (Koch, 1976a). Cardiac output was found to be consistently reduced, and the arteriovenous $\mathrm{O}_{2}$ difference correspondingly increased, during both resting and exercise conditions, after long-term treatment with alprenolol, atenolol, metoprolol, and timolol, while the peripheral vascular resistance consistently showed a tendency towards slightly higher values (Lund-Johansen and $\mathrm{Ohm}, 1976)$. The same general pattern of haemodynamic adjustment was observed after a 13-month treatment with oxprenolol despite supplementary administration of the vasodilator hydralazine in a daily dose ranging between 150 and 225 $\mathrm{mg}$ during the last 6 months (Koch, 1976a). Data obtained during treatment with propanolol, though limited to resting conditions, suggest a similar haemodynamic response (Tarazi and Duston, 1972), even when combined with hydralazine (Trap-Jensen et al., 1976a). A particular feature of Tarazi's study was the observation that systemic vascular resistance was greatly increased in the early stage of treatment, but approached pretreatment levels after a period of 20 months of treatment. Surprisingly enough, pindolol, a nonselective beta-receptor antagonist, has recently been reported to lack the cardiac output reducing effect on long-term treatment and to exert its antihypertensive action solely by reduction of the peripheral vascular resistance (Atterhög et al., 1977). However, the mechanism behind this effect, unusual for a beta-receptor blocker, remains obscure.

The considerable reduction in total peripheral vascular resistance in association with unchanged cardiac output (Fig. 1) suggests that labetalol, because of its alpha-receptor antagonism, might lack the flow reducing effect exerted by propranolol in different vascular beds such as the splanchnichepatic circulation and the skeletal muscle (TrapJensen et al., 1976b). The significant reduction in arterial blood lactate during and after exercise while on prolonged treatment (Table 3) might indicate a different action of labetalol with respect to microcirculation and/or metabolism, since lower lactate levels probably reflect a lesser degree of anaerobic metabolism in the working muscles. A decline of lactate was not seen after the acute administration of labetalol (Koch, 1977) and clonidine (Koch, 1971), or after long-term treatment with propranolol (Trap-Jensen et al., 1976b) and with oxprenolol in combination with hydralazine (Koch, 1976a), that is conditions where cardiac output was consistently reduced. Recent studies on renal haemodynamics have also shown a reduction in renal vascular resistance after the administration of labetalol (Koch, 1978).

During the acute experiment, signs and symptoms of conspicuous postural hypotension were frequent (Koch, 1976b), but were not observed after longterm oral treatment. Neither did any of the patients complain of signs attributable to decreased orthostatic tolerance in daily life activities during a total 
observation period of 3 years. The acute effects of labetalol consist mainly in a negative chronotropic action via beta-receptors in the myocardium and in an alpha-receptor mediated dilatation of the resistance vessels inducing a reduction of cardiac output and predominantly of vascular resistance; but intravenous labetalol also results in lower pulmonary artery pressures and tends to decrease left ventricular filling pressures (Koch, 1977). These latter effects suggest that the acute administration of the drug also induces, particularly in the supine and upright position, a blood volume shift from the intrathoracic to the peripheral compartments of the low pressure capacitance system. This peripheral blood pooling is probably the result of a vasodilatory effect on the venules and small veins as well. Attenuation of this particular effect appears to be the main alteration occurring during long-term treatment since the peripheral vascular resistance tends to decrease further. This would explain both the considerable increase in stroke volume and cardiac output, again most pronounced during resting conditions, and the presence of postural hypotension during the acute experiment but not after long-term treatment. On the other hand, the additional decrease in resting (supine and upright) heart rates suggests a greater influence of the betareceptor blocking action after long-term therapy.

As previously mentioned, adaptive structural changes appear early in the course of hypertension in the precapillary section of the vascular system and the left heart (Folkow, 1975). The precapillary structural adjustment taking the form of an increased wall lumen ratio implies a mutual reinforcement between functional and structural factors, resulting in exaggerated increases of resistance and arterial pressure, for given increases of vascular smooth muscle activity. Furthermore, evidence has recently been provided that both acute and prolonged adrenoceptor blockade results in increased blood levels of adrenaline and noradrenaline. This has been shown to apply not only to non-selective beta-receptor blockers such as propranolol (TrapJensen et al., 1976b) and cardioselective agents such as metoprolol (Koch, unpublished data), respectively, but also to labetalol (Koch, 1978). Raised levels of circulating noradrenaline may be an important factor contributing to the increased vascular resistance regularly observed during acute and short-term beta-receptor blockade, particularly with non-selective antagonists, and to the failure of the vascular resistance to decrease significantly below pretreatment levels during long-term therapy. This implies that additional alpha-receptor blockade is a prerequisite for peripheral vascular resistance to be distinctly lowered and a definite advantage with respect to the interaction between structural changes and functional excitatory influences.

The comparison of intravenous and oral labetalol in this series shows that considerably higher oral doses are required to achieve a blood pressure reduction similar to that obtained with $50 \mathrm{mg}$ intravenous labetalol. This is obviously mainly caused by a considerable first-pass metabolism that reduces bioavailability to about 40 per cent (Brogden et al., 1978). This explains also the need for frequent dose readjustment in the initial stage of treatment if therapy is started with relatively low doses as was the case in this series (Koch, 1976c). However, the fairly high doses ( $2400 \mathrm{mg}$ daily) that had to be used in some of these patients who had not satisfactorily responded to previous treatment with different antihypertensive regimens, were in all cases well tolerated. The complete lack of troublesome side-effects attributable to the drug after a 3 -year continuous treatment in this series is noteworthy.

\section{References}

Atterhög, J. H., Duner, H., and Pernow, B. (1977). Haemodynamic effects of pindolol in hypertensive patients. Acta Medica Scandinavica, Suppl. 606, 55-62.

Brogden, R. N., Heel, R. C., Speight, T. M., and Avery, G. S. (1978). Labetalol: a review of its pharmacology and therapeutic use in hypertension. Drugs, 15, 251-270.

Folkow, B. (1975). Vascular changes in hypertensionreview and recent animal studies. In Pathophysiology and Management of Arterial Hypertension, p. 95. Ed. by G. Berglund, L. Hansson, and L. Werkö. Lindgren and Söner, Mölndal, Sweden.

Koch, G. (1971). Hemodynamic effects of 2-(2,6-dichlorophenylamino) 2-imidazoline hydrochloride (St 155) at rest and during exercise with special respect to the pulmonary circulation. Arzneimittel-Forschung, 21, 57-61.

Koch, G. (1976a). Haemodynamic adaptation at rest and during exercise to long-term antihypertensive treatment with combination of beta-receptor blocking and vasodilator agent. British Heart fournal, 38, 1240-1246.

Koch, G. (1976b). Haemodynamic effects of combined $a$ - and $\beta$-adrenoreceptor blockade after intravenous labetalol in hypertensive patients at rest and during exercise. British Fournal of Clinical Pharmacology, 3, Suppl. 3, 725-728.

Koch, G. (1976c). Combined $\alpha$ - and $\beta$-adrenoreceptor blockade with oral labetalol in hypertensive patients with reference to haemodynamic effects at rest and during exercise. British fournal of Clinical Pharmacology, 3, Suppl. 3, 729-732.

Koch, G. (1977). Acute hemodynamic effects of an alphaand beta-receptor blocking agent (AH 5158) on the systemic and pulmonary circulation at rest and during exercise in hypertensive patients. American Heart fournal, 93, 585591.

Koch, G. (1978). Effect of combined $a$ - and $\beta$-receptor blockade on renal hemodynamics, excretory function, plasma renin and plasma catecholamines in man (abstract). Pflügers Archiv-European fournal of Physiology, 373, R.33. 
Lund-Johansen, P., and Ohm, O. J. (1976). Haemodynamic long-term effects of $\beta$-receptor-blocking agents in hypertension: a comparison between alprenolol, atenolol, metoprolol and timolol. Clinical Science and Molecular Medicine, 51, Suppl. 3, 481s-483s.

Majid, P. A., Meeran, M. K., Benaim, M. E., Sharma, B., and Taylor, S. H. (1974). Alpha- and beta-adrenergic receptor blockade in the treatment of hypertension. British Heart fournal, 36, 588-596.

Richard, D. A., and Turner, P. (1976). (Eds.) Proceedings of a Symposium on labetalol, April 1976. British fournal of Clinical Pharmacology, 3, Suppl. 3.

Sivertsson, R. (1977). Peripheral haemodynamics in essential hypertension. Acta Medica Scandinavica, Suppl. 606, 4354.

Tarazi, R. D., and Duston, H. P. (1972). Beta adrenergic blockade in hypertension. Practical and theoretical implications of long-term hemodynamic variations. American Fournal of Cardiology, 29, 633-640.

Taylor, S. H., Majid, P. A., Saxton, C., and Stoker, J. B. (1970). Comparison of the circulatory effects of oxprenolol and propranolol in hypertensive patients. In Beta-adrenergic Receptor Blocking Drugs, p. 47. Ed. by F. O. Simpson. Published for CIBA Laboratories by Australia Drug Information Services, Horsham, Sussex.
Trap-Jensen, J., Clausen, J. P., Hartling, O., Krogsgaard, A. R., and Noer, I. (1976a). Central and peripheral circulation in patients with hypertension treated with propanolol and hydralazin. Svenska Läkaresällskapets Handlingar, 85, 181.

Trap-Jensen, J., Clausen, J. P., Noer, I., Larsen, O. A., Krogsgaard, A. R., and Christensen, N. J. (1976b). The effect of beta-adrenoceptor blockers on cardiac output, liver blood flow and skeletal muscle blood flow in hypertensive patients (abstract). Acta Physiologica Scandinavica, Suppl. 440, 30.

Weiss, L., Lundgren, Y., and Folkow, B. (1974). Effects of prolonged treatment with adrenergic $\beta$-receptor antagonists on blood pressure, cardiovascular design and reactivity in spontaneously hypertensive rate (SHR). Acta Physiologica Scandinavica, 91, 447-457.

Zacest, R. (1975). The clinical pharmacology of hypotensive vasodilator drugs. Medical fournal of Australia, 1, Suppl. 1, 4-7.

Requests for reprints to Professor G. Koch, Department of Physiology, Freie Universität Berlin, Arnimallee 22, D-1 Berlin 33 (West-Berlin), Germany. 